\title{
Comparison of CSR Activities between Global Construction Companies and Malaysian Construction Companies
}

\author{
Byung Gyoo Kang1*, Hussam Uddin Ahmad², Boon Hoe Goh², Myung Kyu Song2 \\ ${ }^{1}$ Department of Civil Engineering, Xian Jiaotong-Liverpool University, Suzhou, China \\ ${ }^{2}$ Department of Civil Engineering, University of Nottingham Malaysia Campus, Jalan Broga, Malaysia \\ Email: ${ }^{*}$ Byung-Gyoo.Kang@xjtlu.edu.cn
}

Received 9 April 2015; accepted 11 July 2015; published 14 July 2015

\begin{abstract}
Corporate Social Responsibility (CSR) is becoming a new requirement for a successful business in the 21st century. This trend continues to be strengthened throughout the industry and the construction industry cannot be exceptional. Extensive literature reviews on CSR in the construction industry have been conducted to find out the current status. Ten leading construction companies in the global construction market have been selected and their CSR reports have been analysed in five broad areas-“Leadership, visions and values", "Workforce activities", "Stakeholder engagement", "Community activities", and "Environmental activities". Five-Malaysian construction companies have been selected, each representing a different range of turnovers to reflect the industry wide perspective. Comparisons have been made between global companies and Malaysian companies, resulting in large gaps between these two groups. Qualitative interviews have been conducted with the executives of the Malaysian companies to identify the causes of the gaps. The interview questions included CSR reporting, funding, Key Performance Indicators (KPI), challenges of CSR implementation, roles of government, CSR initiatives, future CSR activities, etc. CSR commitments of global construction companies have been identified and the current status of CSR of Malaysian companies has been grasped. The comparison shows that Malaysian companies lag behind global companies in almost all aspects of CSR. The obstacles have been found out to be studied in future-financial constraints, management attitudes, roles of government, and the trend of CSR in the industry.
\end{abstract}

\section{Keywords}

CSR, Global, Construction, Company

\section{Introduction}

"Sustainable development" is an idea of ensuring a better quality of life which aims to protect the environment, enhance social progress and sensible use of natural resources and maintain a positive stable economic growth. In the construction industry, a new paradigm called "sustainable construction" is becoming prevalent to reflect the ${ }^{*}$ Corresponding author.

How to cite this paper: Kang, B.G., Ahmad, H.U., Goh, B.H. and Song, M.K. (2015) Comparison of CSR Activities between Global Construction Companies and Malaysian Construction Companies. Open Journal of Social Sciences, 3, 92-98. 
application of sustainable development to construction [1] [2]. The foundation of sustainable construction is based on economic, social and environmental concerns of construction projects [3]. Construction companies are aware that they can practice sustainable construction by managing their operations in such a way as to enhance economic growth and increase competitiveness while at the same time protecting the environment and staying committed to social responsibilities [4]. At present, sustainable construction techniques are more focused on environmental concerns than economic and social concerns, which can be identified from two leading organizations of sustainable construction in UK-Building Research Establishment and Institute of Civil Engineers, and the leading organization in USA-US Green Building Council [5]-[7]. Typically, the evaluation of sustainable construction includes not only design and construction but also operation \& maintenance phases of construction projects [8] [9]. The main causes of this environmental approach are laws and regulations related to construction projects such as Environmental Impact Assessment (EIA) and Environmental Management System (EMS) [10] [11]. Similarly, Corporate Social Responsibility (CSR) is concerned on economic, social and environmental aspects. In the construction industry, CSR and sustainable construction overlap in many aspects and sometimes they are used interchangeably. In terms of good CSR practices, companies are expected to "do more" than what is legally required. This leads to corporations being more innovative and forthcoming in their CSR programmes and capabilities. In other words, companies should be held responsible for the effects of their actions. The construction industry plays an important role in shaping human settlements and dictating lifestyles; hence, the process of identifying social aspects and how these are affected need to be streamlined for easier implementation. In addition, CSR is becoming a new requirement for a successful business in the 21 st century. This trend continues to be strengthened throughout the industry and the construction industry cannot be exceptional. Therefore, to investigate the roles of CSR in the construction industry will also help broaden and deepen the new paradigm "sustainable construction". It seems that CSR activities in Malaysia are not active enough to reflect the global advancement of corporate citizenship, compared with those in developed countries. In addition, the current address of CSR in the Malaysia construction industry can be hardly better than those of the industry average in Malaysia, considering the features of construction. The construction industry is unique and different from manufacturing or factory based industries. In manufacturing or factory based industries, mass production methods are common practice and stakeholders are related to business. However, in the construction industry, most projects tend to be one-off and the stakeholders are related to the project. The major stakeholders in construction are the participants of the project, clients, designers (architects/engineers), contractors (sub-contractors) and suppliers. The construction industry is typically project-based and short-term oriented, compared to other industries. Therefore it is worth conducting a research on CSR in the Malaysia construction industry.

The objectives of the research is to investigate the state-of-the-art CSR activities of global construction corporations in the 21 st century and compare them with CSR activities of Malaysian construction corporations, and to suggest future areas of research pertaining to CSR in the construction industry.

\section{Research Methodology}

Both quantitative and qualitative approaches were adopted in this research. In the quantitative approach, data were gathered by visiting United Nations Global Compact (UNGC) website or company websites. In qualitative approach, interviews were conducted with top executives of Malaysian construction companies to find out the causes and/or shortfalls they face under the current CSR practice. Through the quantitative approach the trends of CSR activities of global construction companies are induced and generalized. The causes of the gaps between global construction companies and Malaysia companies in respect of CSR activities are deduced and identified through the qualitative approach. The concept of induction and deduction are applied to provide clear directions of the research methods. For the survey and collection of data a two-way communication approach was applied. This enabled the gathering of data via probing and semi-structured interviews and personal observations. Both open and close ended questions were asked to get a broad scope of the extent of understanding of CSR and its applications.

\section{CSR Activities of Global Construction Corporations}

There is a range of CSR initiatives in the construction industry that advocate or aspire to higher standards. Keeping these in mind and in order to consider the construction industry's engagement of CSR in a more granu- 
lar way, an analysis of ten corporations was conducted. The method of selection was to utilize publicly available material via their Communication on Progress (COP) reports from the United Nation's Global Compact (UNGC) website or the corporations' websites, with a consideration of geographical allocation. The publication of their CSR activities is seen as an expression of the respective company's commitment towards public discourse and interest regarding CSR. The following global construction corporations were selected:

1) ARUP of United Kingdom;

2) BECHTEL of United States of America;

3) HALCROW of United Kingdom;

4) LARSEN \& TOUBRO of India;

5) MURRAY \& ROBERTS of South Africa;

6) ORASCOM CONSTRUCTION INDUSTRIES of Egypt;

7) SCOTT WILSON of United Kingdom;

8) SKANSKA of Sweden;

9) SNC LAVALIN of Canada;

10)TAISEI CONSTRUCTION CORPORATION of Japan.

The analysis criteria have been built upon by combining clauses from the United Nation's Global Compact (UNGC) Communication on Progress (COP) and the Global Reporting Initiative (GRI) reporting framework. The UNGC advises and helps collaborations between UN agencies, labour, civil society and governments to practise ten universal principles in the areas of human rights, labour, environment and anti-corruption. The framework prescribed by GRI can be used for a wide range of organizations regardless of size, location, or the geographic region of origin or operation. GRI is composed of economic, environmental and social aspects, subdividing the economic aspect into labour practices, human rights, society and product responsibility. The areas of analysis are hence based on the original criteria given by these two internationally recognized reporting guidelines. The summarised analysis of the ten organizations has been recorded in Table $\mathbf{1}$.

It can be noted that all of the analysed criteria are found to be affirmative. The analysis shows that these companies are well aware of CSR and are involved in the related activities. It can also be seen that CSR activities have impacts on the way they conduct business and manage their workplaces. However in some cases there was not sufficient information on their respective websites, or even in the annual CSR reports, hence the outcome is recorded as "uncertain". A UK construction company, Arup, provides much detailed information on their CSR activities, such as strategies and plans which indicates that CSR is an internalized part of the company's corporate culture. Another notable UK construction company, Halcrow, shows significant details about their CSR commitments to combat the shortage and scarcity of safe drinking water in developing countries. The case study indicates that these companies are at different stages of CSR development and can be regarding as being in the phase of a good corporate citizenship. All the websites and reports provide indications that the companies have set certain benchmarks and definitive goals to be achieved in order to incorporate CSR initiatives and values. From the published reports and web sites, the following CSR indications can be gauged:

- Collaboration with suppliers, clients and markets about the social and environmental sustainability of products, projects and activities.

- Supporting the community through their development activities.

- Establishing grant giving programmes or welfare foundations.

- Employee volunteerism, charity runs, fund raising.

Most companies have been involved with disaster reliefs and management in regions of either natural calamities or countries ravaged by war. Although this was a drain on the company's resources and skills expertise, the services were rendered willingly and in the best spirit of philanthropy. These acts of either resource or skilled manpower donations, in the long run prove to be learning experiences as well as skill sharing and developing exercises. In some cases such as Orascom Construction Industries (OCI), philanthropic activities have led to growth in demand in a war ravaged country, Afghanistan, starting to rebuild the country.

\section{The Survey Undertaken: CSR in Malaysian Construction Corporations}

The Malaysian government, for the past few years, has been active towards issuing initiatives for setting out guidelines and laws relevant for the furtherance of CSR such as tax incentives. In the interest of greater produc- 
Table 1. CSR commitments of global construction corporations.

\begin{tabular}{|c|c|c|c|c|c|c|c|c|}
\hline \multirow[t]{2}{*}{ No. } & \multicolumn{3}{|c|}{ Leadership, Visions and Values } & \multicolumn{3}{|c|}{ Workforce Activities } & \multicolumn{2}{|c|}{ Environmental Activities } \\
\hline & $\begin{array}{l}\text { Visions and } \\
\text { Values }\end{array}$ & $\begin{array}{l}\text { Policies and } \\
\text { Procedures }\end{array}$ & $\begin{array}{c}\text { Ethical } \\
\text { Leadership }\end{array}$ & $\begin{array}{c}\text { Employee } \\
\text { Communication } \\
\text { and Representation }\end{array}$ & $\begin{array}{l}\text { Employability and } \\
\text { Skills Development }\end{array}$ & $\begin{array}{l}\text { Diversity and } \\
\text { Equality }\end{array}$ & $\begin{array}{l}\text { Resource and } \\
\text { Energy Use }\end{array}$ & $\begin{array}{l}\text { Pollution and } \\
\text { Waste } \\
\text { Management }\end{array}$ \\
\hline 1 & Yes & Yes & Yes & Yes & Yes & Yes & Yes & Yes \\
\hline 2 & Yes & Yes & Yes & Yes & Yes & Yes & Yes & Yes \\
\hline 3 & Yes & Yes & Yes & Yes & Yes & & Yes & Yes \\
\hline 4 & Yes & Yes & Yes & Yes & Yes & Yes & Yes & Yes \\
\hline 5 & Yes & Yes & Yes & Yes & Yes & Yes & Yes & Yes \\
\hline 6 & Yes & Yes & Yes & Yes & Yes & Uncertain & Yes & Yes \\
\hline 7 & Yes & Yes & Yes & Yes & Yes & Yes & Yes & Yes \\
\hline 8 & Yes & Yes & Yes & Yes & Yes & Yes & Yes & Yes \\
\hline 9 & Yes & Yes & Yes & Yes & Yes & Uncertain & Yes & Yes \\
\hline 10 & Yes & Yes & Yes & Yes & Yes & Uncertain & Yes & Yes \\
\hline \multirow[t]{2}{*}{ No. } & \multicolumn{5}{|c|}{ Stakeholder Engagement } & \multicolumn{3}{|c|}{ Community Activities } \\
\hline & $\begin{array}{l}\text { Note of K } \\
\text { Stakeholde }\end{array}$ & $\begin{array}{l}\text { Stak } \\
\text { Cons }\end{array}$ & $\begin{array}{l}\text { eholder } \\
\text { ultation } \quad \mathrm{St}\end{array}$ & $\begin{array}{l}\text { Managing and } \\
\text { Notifying } \\
\text { takeholder Concerns }\end{array}$ & $\begin{array}{l}\text { Transparent } \\
\text { Reporting }\end{array}$ & $\begin{array}{l}\text { Financial } \\
\text { Donations }\end{array}$ & $\begin{array}{c}\text { Volunteer } \\
\text { Employee Time }\end{array}$ & Charity Runs \\
\hline 1 & Yes & & Yes & Yes & Yes & Yes & Yes & Yes \\
\hline 2 & Yes & & Yes & Yes & Yes & Yes & Yes & Yes \\
\hline 3 & Yes & & Yes & Yes & Yes & Yes & Yes & Yes \\
\hline 4 & Yes & & Yes & Yes & Yes & Yes & Yes & Yes \\
\hline 5 & Yes & & Yes & Yes & Yes & Yes & Yes & Yes \\
\hline 6 & Yes & & Yes & Yes & Yes & Yes & Uncertain & Yes \\
\hline 7 & Yes & & Yes & Yes & Yes & Yes & Yes & Yes \\
\hline 8 & Yes & & Yes & Uncertain & Yes & Yes & Yes & Yes \\
\hline 9 & Yes & & Yes & Yes & Yes & Yes & Yes & Yes \\
\hline 10 & Yes & Un & ertain & Yes & Uncertain & Yes & Yes & Yes \\
\hline
\end{tabular}

tivity, the government along with its market regulators has called for greater corporate responsibility programmes to be introduced in the industries. Public listed and state owned companies are encouraged to give more resources towards building a CSR culture, in the best interests of better profitability, brand security and productivity in the global market as well as the domestic market. However it seems that the outcomes of these efforts have not been clearly revealed yet. The situation is not much different, especially for the Malaysian construction industry. To identify the extent of the awareness and practice of CSR in the Malaysian construction industry, a survey incorporated with interviews was conducted. Executives from five different companies were interviewed each representing a different annual turnover, to get an industry wide perspective.

\section{Findings of the Survey}

\subsection{Findings of the Survey on Malaysian Construction Companies}

To reflect the true address of CSR in the Malaysian construction industry, the five Malaysian companies with 
different ranges of annual turnover were surveyed, ranging from RM 5 million for the small specialist firm to more than RM 50 million for the largest company. The latter company has also undertaken major operations overseas in the South East Asian region and the Middle East. CSR reporting is not adopted by the companies except the public listed company, as private companies are not obliged to do so under legal requirements in Malaysia. Therefore direct comparisons between global companies and Malaysian companies were not possible in this research. Indirect comparison have been made and discussed in detail. The primary findings of the survey are explained below. Table 2 shows the summary of the finding $\mathrm{s}$ of the survey.

Table 2. Summary of the findings of the survey.

\begin{tabular}{|c|c|c|c|c|}
\hline Company A & Company B & Company $\mathrm{C}$ & Company D & Company E \\
\hline \multicolumn{5}{|c|}{ Company Profile } \\
\hline $\begin{array}{l}\text { Geotechnical } \\
\text { Engineering }\end{array}$ & Construction & Traffic Engineering & Construction & Construction, Project Management \\
\hline Malaysia, Singapore & Malaysia & Malaysia & Malaysia & Malaysia, S.E. Asia, Middle east \\
\hline \multicolumn{5}{|c|}{ Annual Turnaround } \\
\hline $\begin{array}{l}\text { Less than RM } 5 \\
\text { million }\end{array}$ & RM 5 - 10 million & RM 10 - 50 million & RM 10 - 50 million & More than RM 50 million \\
\hline \multicolumn{5}{|c|}{ Project Sectors } \\
\hline Private sector & Private sector & Public sector & Both private and public & Both private and public \\
\hline \multicolumn{5}{|c|}{ Custodian of CSR program } \\
\hline Director & Manager, External Affairs & None & Manager, External Affairs & $\begin{array}{c}\text { Manager, Business Dynamics } \\
\text { Department }\end{array}$ \\
\hline \multicolumn{5}{|c|}{ CSR Reporting } \\
\hline None & None & None & None & $\begin{array}{l}\text { Annual CSR report } \\
\text { Website publications }\end{array}$ \\
\hline \multicolumn{5}{|c|}{ Funding for CSR } \\
\hline Self-funded & Self-funded & Self-funded & Self-funded & $\begin{array}{c}\text { Self-funded } \\
\text { Client donations }\end{array}$ \\
\hline \multicolumn{5}{|c|}{ Potential KPI's in Measuring CSR Activities } \\
\hline None & Strategic partners & None & $\begin{array}{l}\text { Social and economic } \\
\text { investments }\end{array}$ & $\begin{array}{c}\text { Social and economic investments } \\
\text { Strategic partners } \\
\text { Energy conservation }\end{array}$ \\
\hline \multicolumn{5}{|c|}{ Current CSR Activities } \\
\hline $\begin{array}{l}\text { Training courses } \\
\text { Donations } \\
\text { Waste minimization }\end{array}$ & $\begin{array}{l}\text { Training courses } \\
\text { Donations }\end{array}$ & $\begin{array}{l}\text { Training courses } \\
\text { Employee benefits } \\
\text { Donations }\end{array}$ & $\begin{array}{l}\text { Training courses } \\
\text { Donations }\end{array}$ & $\begin{array}{c}\text { Training courses } \\
\text { Employee benefits } \\
\text { Community development }\end{array}$ \\
\hline \multicolumn{5}{|c|}{ Further CSR Activities to Be Initiated } \\
\hline $\begin{array}{c}\text { Workplace ethics } \\
\text { Health \& safety } \\
\text { Social and environment } \\
\text { awareness }\end{array}$ & $\begin{array}{l}\text { Employee welfare and } \\
\text { training } \\
\text { Social and } \\
\text { environmental } \\
\text { awareness }\end{array}$ & Health \& safety & $\begin{array}{l}\text { Health \& safety } \\
\text { Employee welfare and } \\
\text { training }\end{array}$ & Economic, social, environmental \\
\hline \multicolumn{5}{|c|}{ Challenges in Implementation } \\
\hline $\begin{array}{l}\text { Money } \\
\text { Trends of the industry }\end{array}$ & $\begin{array}{c}\text { Money } \\
\text { Employee willingness }\end{array}$ & $\begin{array}{c}\text { Money } \\
\text { Top management attitude }\end{array}$ & $\begin{array}{l}\text { Money } \\
\text { Trends of the industry }\end{array}$ & $\begin{array}{l}\text { Trends of the industry Government } \\
\text { incentives Top management attitude }\end{array}$ \\
\hline \multicolumn{5}{|c|}{ Government Interference } \\
\hline Yes, certain \% & Yes, very much & Yes, certain \% & Yes, certain \% & Yes, very much \\
\hline \multicolumn{5}{|c|}{ Effect of Government Regulations } \\
\hline Positively \& negatively & Positively \& negatively & Positively & Positively \& negatively & Positively \\
\hline \multicolumn{5}{|c|}{ CSR in the Next 5 Years } \\
\hline $\begin{array}{l}\text { Gradual implantation, } \\
\text { at a rather slow pace }\end{array}$ & $\begin{array}{l}\text { Not much, industry } \\
\text { attitude needs to be } \\
\text { changed first }\end{array}$ & $\begin{array}{l}\text { Yes, good progress. } \\
\text { Important for overseas } \\
\text { growth } \\
\end{array}$ & & $\begin{array}{l}\text { Construction industry is a major } \\
\text { growth area. Therefore CSR } \\
\text { perspectives are well sought after. }\end{array}$ \\
\hline
\end{tabular}


There is a lack of awareness and recognition of CSR activities among the smaller entities. Although they might be involved in training programmes for skill developments of employees, they do not term these as CSR. The reason for this can be the attitude of top management who are reluctant to make changes and accept new environments as long as the business is profitable. In the hierarchical structure, none of the companies have a dedicated CSR division. Instead CSR is recorded under external affairs. In some cases it is divided between the human resource division (for internal employee issues) and external affairs (for community issues). This can lead to confusion as there are no clear lines of separation and internal conflicts of interests can easily take place. According to the answers, four out of five companies do not have a CSR policy statement. This highlights the lack of government initiatives and motivations for smaller entities. However, good potential KPIs (Key Performance Indicators) for measuring CSR activities can be identified such as 'collaboration with strategic partners' and 'investments in social and economic sectors'. From the answers of the questionnaire it has been found that all companies made some form of donations in the nature of philanthropy according to their individual standings. However it does not seem to be regular donations of charity. Training programmes and courses for employees are increasingly being considered especially for the managerial staff, as this expense can be claimed under the governments human resource development fund (HRDF). One of the questions is targeted towards the further CSR activities which should be initiated in the Malaysian construction industry. The findings show that employee concerns and social and environmental awareness are generally recognised as further CSR activities. Improvements for the health and safety aspects of construction sites and labourers are seen as very important. To remain competitive, continual employee training and acquiring new technologies and operation methods seem to be essential. From the questionnaire, it was attained that the first obstacle to initiate CSR activities is the monetary aspect. This again emphasizes the bias of the industry between big corporations and their smaller counterparts. Other major obstacles are "trends of the industry" and "top management attitude". Awareness regarding the CSR framework provided by Bursa Malaysia (the stock exchange in Malaysia) does not influence the small companies. The framework is recognized by medium and large companies only.

\subsection{Comparisons between Global Companies and Malaysian Companies}

Malaysian companies lag behind global companies in almost all aspects regarding CSR. The current corporate policies and government policies need to be improved to reflect the requirements of sound CSR activities, especially for those SMEs (Small and Medium Enterprises). Malaysian companies need to clarify and set the visions and values of CSR for their own companies. Malaysian companies show some limited commitments in workforce and employment concerns. More comprehensive and detailed programmes should be developed to cope with the various demands rising from various levels of employees in the construction projects. The concepts of stakeholders should be clearly established, especially the internal ones and external ones to the projects, together with their roles and responsibilities. Malaysian companies also need to develop the community programmmes not only at company levels but also at project levels. The environmental activities can be effectively improved if these are incorporated into current legal requirements such as Environmental Impact Assessment (EIA). A comparison between the global and Malaysian companies is interpreted in Table 3 highlighting the common and basic aspects of incorporating CSR activities and values.

Table 3. Comparisons between global companies and Malaysian companies.

\begin{tabular}{|c|c|c|}
\hline & Global Companies & Malaysian Companies \\
\hline $\begin{array}{l}\text { Leadership, Visions } \\
\text { and Values }\end{array}$ & $\begin{array}{l}\text { Clearly defined, part of company governance structure. Dedicated CSR } \\
\text { departments to advice towards better policies and procedures. }\end{array}$ & $\begin{array}{l}\text { Not clear. } \\
\text { Nothing specific. }\end{array}$ \\
\hline $\begin{array}{l}\text { Workforce } \\
\text { Activities }\end{array}$ & $\begin{array}{l}\text { Done on a regular basis to gauge employee satisfaction and strive toward } \\
\text { creating a more conducive working environment. Training programs, } \\
\text { workshops etc. conducted on a regular basis. }\end{array}$ & $\begin{array}{l}\text { Uncertain, although trend seems } \\
\text { to be changing. } \\
\text { Some training programs conducted. }\end{array}$ \\
\hline $\begin{array}{l}\text { Stakeholder } \\
\text { Engagement }\end{array}$ & $\begin{array}{l}\text { Note of all key stakeholders is kept and the issues } \\
\text { addressed in the best interests of CSR. }\end{array}$ & $\begin{array}{l}\text { Depends on individual } \\
\text { company policy. }\end{array}$ \\
\hline $\begin{array}{l}\text { Community } \\
\text { Activities }\end{array}$ & A certain percentage of profit is earmarked at the start of each financial year & Done but at a very minimal level. \\
\hline $\begin{array}{l}\text { Environmental } \\
\text { Activities }\end{array}$ & Thoroughly undertaken & Not clear. \\
\hline
\end{tabular}




\section{Conclusion}

Through the analyses of CSR activities of ten global construction companies, it was found that these companies could be considered as the leaders in the global construction market in respect of CSR, showing good corporate citizenships. These analyses were conducted through Communication on Progress (COP) reports from the United Nation's Global Compact (UNGC) website or the companies' websites. The interview survey with five Malaysian companies identified the current address of CSR activities in the Malaysian construction industry. The Malaysian companies lag behind the global companies almost in all aspects of CSR activities including "Leadership, visions and values", "Workforce activities", "Stakeholder engagement", "Community activities" and "Environmental activities". The interviews also revealed the obstacles the industry faced to implement sound CSR activities. These include internal matters such as the attitude of top management, no clear lines of responsibilities, financial constraints and external matters such as government initiatives and motivations, and the trends of the industry in respect to CSR. Therefore, to achieve a good improvement not only company level commitments but also government and industry level drives should be implemented. It is clear that to be competitive in the global construction market as well as the domestic market, Malaysian companies must incorporate CSR initiatives into their management programmes in terms of both quantity and quality. In addition, the Malaysian government needs to provide policies and strategies for the companies. This will help the companies to develop and implement practical and fruitful CSR activities. Investigating CSR in the Malaysian construction industry is a new area of research especially in construction management Asia. Consecutive researches will be conducted on CSR in the Malaysian construction industry in terms of both breadth and depth to help not only the industry but also the society as CSR explicitly implies. Further considering the project based nature of the construction industry, a project level approach as well as a company level approach might help establish effective and efficient CSR policies. Especially the neighboring communities to the construction sites, work environments and various levels of workers of construction projects will be good targets to produce tangible and fruitful outcomes of CSR activities. These will be good future research areas in CSR in the construction industry, especially for the developing countries.

\section{References}

[1] Matar, M.M. (2008) Sustainable Construction Management: Introduction of the Operational Context Space (OCS). Construction Management \& Economics, 26, 261-275.

[2] Shiers, D., Rapson, D., Roberts, C. and Keeping, M. (2006) Sustainable Construction: The Development and Evaluation of an Environmental Profiling System for Construction Products. Construction Management \& Economics, 24, 1177-1184.

[3] Constructing Excellence (2014) Draft Strategy for Sustainable Construction. A Consultation Paper July 2007. http://www.constructingexcellence.org.uk

[4] Murray \& Roberts (2014) Murray \& Roberts. http://www.murrob.com/au_overview.asp

[5] BRE Global (2014) The World's Leading Design and Assessment Method for Sustainable for Buildings. http://www.breeam.org/index.jsp

[6] CEEQUAL Ltd. (2014) Sustainability Assessment and Awards Scheme for Civil Engineering, Infrastructure, Landscaping and the Public Realm. http://www.ceequal.com/index.html

[7] US Green Building Council (2014) LEED Leadership in Energy and Environmental Design. http://www.usgbc.org/DisplayPage.aspx?CategoryID=19

[8] Martland, C.D. (2012) Toward More Sustainable Infrastructure: Project Evaluation for Planners and Engineers. Wiley.

[9] Leffers, M.R. (2010) Sustainable Construction and Design. Pearson/Prentice Hall.

[10] Tam, V.W.Y., Tam, C.M., Shen, L.Y., Zeng, S.X. and Ho, C.M. (2006) Environmental Performance Assessment: Perceptions of Project Managers on the Relationship between Operational and Environmental Performance Indicators. Construction Management \& Economics, 24, 287-299

[11] Terio, O. and Kashkonen, K. (2011) Developing and Implementing Environmental Management Systems for Small and Medium-Sized Construction Enterprises. Construction Management \& Economics, 29, 1183-1195. 